PENELITIAN

\title{
PENGARUH REMOTE ISCHEMIC PRECONDITIONING TERHADAP ANGKA KEJADIAN ARITMIA DAN ACUTE KIDNEY INJURY PADA PASIEN DEWASA PASCA OPERASI BEDAH JANTUNG
}

\section{REMOTE ISCHEMIC PRECONDITIONING IMPACT TOWARDS ARRHYTMIAS AND ACUTE KIDNEY INJURY PREVALENCE ON ADULTS AFTER CARDIAC SURGERY}

\author{
Dedy Fachrian*, M. Sofyan Harahap** \\ *Peserta program pendidikan dokter spesialis Anestesiologi dan Terapi Intensif FK Undip/RSUP Dr. \\ Kariadi \\ ** Staff pengajar program pendidikan dokter spesialis Anestesiologi dan Terapi Intensif FK Undip/ \\ RSUP Dr. Kariadi
}

*Korespondensi/Correspondence: dedyfachrian@gmail.com

\section{ABSTRACT}

Background: Reperfusion injury (IRI) as a result of aortic clamp time of cardiac surgery resulted in the death of cardiomyocytes, malfunctioning of cardiac contractility, arrhythmia, and death. The use of CPB also lead to acute kidney injury (AKI) that the prevalence was $30 \%$. To prevent this is to prepare the myocardium against the adverse effects of aorta clamping. Preconditioning the myocardium is basically to increase the stimulation of the innate cardioprotective mechanism ischemia through administration of non lethal ischemic that does periodically. Giving short duration of ischemic to skeletal muscle using cuff pressure at the arm or leg periodically can provide protection to the myocardium and the kidneys from IRI. This is expected to prevent arrhythmias and AKI after cardiac surgery.

Objective: Does RIPC can prevent arrhythmia and AKI after cardiac surgery with aortic clamping and CPB machine uses.

Method: This study is a randomized controlled clinical trials. With sample of 30 patients divided into 2 groups: control group $(K) 15$ subjects and treatment $(P) 15$ subjects. The treatment group after induction of anesthesia and prior to sternotomy will be given RIPC procedure by inflated the cuff on one arm up to $200 \mathrm{mmHg}$ and maintained for 5 minutes and then cuff is deflated then it is maintained up to 5 minutes. The cycle is then repeated so the procedure lasts for 20 minutes. While in the control group cuff attached to one arm on the subject and left uninflated for 20 minutes. During operation duration of aortic ligation is measured and if the duration of aortic ligation more than 20 minutes, the study continued, but if the duration less than 20 minutes, the subject is dropped out of the study. After the opening of the aortic ligation, monitoring to arrhythmias begin up to 24 hours ahead. Once the operation is completed and the patient transferred to ICU, at 12, 24, 36, 48, 60 and 72 hours of treatmen, production of urine and blood samples and serum creatinine levels checked.

Results: Arrhythmia was found in 11 control subjects and 2 treated subjects with 
Atrial Fibrillation as type of arrhythmia is mostly obtained which is 9 subjects in control and 1 subject on treatment group. AKI was found in 11 control subjects and 1 treatment subject. From the Mann-Whitney test, it is found that the decrease in the incidence of arrhythmias in the treatment group were significantly different $(p=0.01)$ and the decrease in the incidence of AKI in the treatment group were significantly different $(p=0.04)$.

Conclution: RIPC with 2 cycles of ischemia and reperfusion in the experimental group had significantly reduce the incidence of postoperative cardiac surgery arrhythmias and AKI compared to the control group.

Keywords: Remote ischemic preconditioning, arrhythmias, Acute Kidney Injury.

\section{ABSTRAK}

Latar Belakang: Cedera reperfusi (IRI) akibat klem aorta saat operasi jantung mengakibatkan kematian kardiomiosit, gangguan fungsi kontraktilitas jantung, aritmia, dan kematian. Penggunaan CPB juga memicu terjadinya acute kidney injury (AKI) yang prevalensinya mencapai 30\%. Salah satu pencegahannya adalah mempersiapkan miokardium terhadap efek buruk dari klem aorta. Mempersiapkan (preconditioning) miokardium ini pada dasarnya adalah untuk meningkatkan stimulasi dari mekanisme kardioprotektif bawaan melalui tindakan pemberian iskemia yang tidak mematikan secara periodik. Pemberian iskemik pada otot rangka lengan atau tungkai dengan menggunakan manset bertekanan secara periodik dan durasi yang singkat dapat memberikan proteksi pada miokardium dan ginjal dari IRI. Hal ini diharapkan dapat mencegah aritmia dan AKI setelah operasi jantung.

Tujuan: Mengetahui apakah RIPC dapat mencegah aritmia dan Acute Kidney Injury (AKI) pada pasien setelah operasi bedah jantung dengan klem aorta dan menggunaan mesin $C P B$.

Metode: Penelitian ini merupakan jenis uji klinis acak terkontrol. Sampel sebanyak 30 pasien yeng terbagi menjadi 2 kelompok yaitu kelompok kontrol (K) 15 subjek dan perlakuan (P) 15 subjek. Kelompok perlakuan setelah dilakukan induksi anestesi dan sebelum dilakukan sternotomi akan diberikan prosedur RIPC yaitu dengan melakukan pengembangan manset pada salah satu lengan atas sampai $200 \mathrm{mmHg}$ dan dipertahankan selama 5 menit kemudian manset di kempiskan dan hal ini dipertahankan sampai 5 menit. Siklus ini kemudian diulangi lagi sehingga lama prosedur ini memakan waktu selama 20 menit. Sedangkan pada kelompok kontrol manset dipasang pada salah satu lengan atas subjek dan dibiarkan tidak dikembangkan selama 20 menit. Selama operasi lama tindakan ligasi aorta diukur dan jika lama ligasi aorta lebih dari 20 menit maka penelitian dilanjutkan tetapi jika lama ligasi aorta kurang dari 20 menit maka subjek penelitian di drop out dari penelitian. Setelah dilakukan pembukaan ligasi aorta, pemantauan akan adanya aritmia dimulai 
sampai 24 jam kedepan. Setelah operasi selesai dan pasien di transfer ke ICU, pada perawatan jam ke 12, 24, 36, 48, 60 dan 72 jam perawatan dilakukan pemantauan produksi urine dan pengambilan sampel darah dan diperiksa kadar serum kreatinin.

Hasil: Aritmia didapatkan pada 11 subjek kontrol dan 2 subjek perlakuan dengan Atrial Fibrilasi merupakan jenis aritmia yang paling banyak didapatkan yaitu 9 subjek pada kontrol dan 1 subjek pada perlakuan. AKI didapatkan pada 11 subjek kontrol dan 1 subjek perlakuan. Pada uji Mann-Whitney didapatkan penurunan angka kejadian aritmia pada kelompok perlakuan yang berbeda bermakna $(p=0,01)$ serta penurunan angka kejadian AKI pada kelompok perlakuan yang berbeda bermakna $(p=0,04)$.

Kesimpulan: Tindakan RIPC dengan 2 siklus iskemia dan reperfusi pada kelompok perlakuan terbukti menurunkan angka kejadian aritmia dan AKI pasca operasi jantung secara bermakna dibanding kelompok kontrol.

Kata kunci: Remote ischemic preconditioning, Aritmia, Acute Kidney Injury.

\section{PENDAHULUAN}

Penyakit kardiovaskular masih menjadi penyebab utama kematian dan kecacatan di seluruh dunia, dengan angka kematian 17 juta pada tahun 2008, dan penyakit jantung iskemik (IHD) merupakan penyebab utama. Operasi coronary artery bypass graft (CABG) adalah terapi pilihanpada pasien IHD dengan dengan kelainan arteri koroner multipel. ${ }^{1}$

Tindakan penghentian aliran darah sementara dengan klem pada operasi jantung mengakibatkan cedera iskemia pada jantung dan tindakan pengaliran kembali darah ke jantung dapat mengakibatkan cedera reperfusi yaitu ischaemia-reperfusion injury(IRI) mengakibatkan kematian kardiomiosit, gangguan fungsi kontraktilitas jantung, aritmia, risiko timbulnya gagal jantung dan kematian. Aritmia sangat sering terjadi setelah operasi jantung dan berhubungan dengan peningkatan angka kematian setelah operasi jantung. ${ }^{1-4}$

$\begin{array}{llr}\text { Penghentian } & \text { aliran darah ke } \\ \text { jantung juga } & \text { disertai } & \text { dengan } \\ \text { penggunaan } & \text { mesin } & \text { pintas }\end{array}$
kardiopulmoner (CPB). Penggunaan CPB merupakan faktor risiko terjadinya acute kidney injury (AKI) setelah operasi bedah jantung, karena CPB memprovokasi sindrom respon inflamasi sistemik. Prevalensi dari AKI post operasi bedah jantung dapat mencapai $30 \%$ yang berhubungan dengan peningkatan mortalitas, lama rawat inap dan risiko infeksi. ${ }^{5}$

Iskemia miokard akibat klem 
aorta telah banyak dipelajari dan diteliti. Salah satu pencegahannya adalah mempersiapkan miokardium terhadap efek buruk dari klem aorta. Mempersiapkan (preconditioning) miokardium untuk periode iskemik pada dasarnya adalah untuk meningkatkan stimulasi dari mekanisme kardioprotektif bawaan melalui tindakan pemberian iskemia yang tidak mematikan secara periodik. Stimulus dapat dilakukan sebelum, selama atau setelah periode iskemia yang panjang. Tindakan ini telah terbukti dalam mengurangi kerusakan organ. ${ }^{6,7}$

Pemberian iskemik pada otot rangka lengan atau tungkai dengan menggunakan manset bertekanan secara periodik dan durasi yang singkat dapat memberikan proteksi pada miokardium dan ginjal dari IRI. Hal ini diharapkan dapat mencegah aritmia dan AKIsetelah operasi jantung dengan tindakan klem aorta dan pengunaan CPB. ${ }^{5,7-9}$

\section{METODE}

Pasien akan dibedakan menjadi kelompok kontrol dan kelompok perlakuan. Subjek penelitian sesuai kriteria inklusi dan ekslusi yang akan menjalani operasi bedah jantung elektif diberikan edukasi dan informed consent tentang penelitian yang akan dilakukan.

Kriteria inklusi adalah usia $>18$ tahun dan menjalani operasi bedah jantung elektif dengan mesin CPB dan lama klem aorta $>20$ menit. Sedangkan kriteria eksklusi adalah pasien dalam kondisi hamil, memiliki penyakit pembuluh darah perifer yang signifikan pada kedua lengan, kadar serum ureum $(>50 \mathrm{mg} / \mathrm{dL})$ dan kreatinin $(>1,5 \mathrm{mg} / \mathrm{dL})$ diatas normal sebelum operasi, memiliki gangguan irama jantung yang terdeteksi dari EKG sebelum operasi dan dalam pengobatan dengan glibenklamid.

Pada hari operasi, induksi dan tekhnik anestesi sesuai dengan DPJP anestesi pasien tersebut. Pada kelompok perlakuan setelah dilakukan induksi anestesi dan sebelum dilakukan sternotomi akan diberikan prosedur RIPC yaitu dengan melakukan pengembangan manset pada salah satu lengan atas sampai $200 \mathrm{mmHg}$ dan dipertahankan selama 5 menit kemudian manset di kempiskan dan hal ini dipertahankan sampai 5 menit. Siklus ini kemudian diulangi lagi sehingga lama prosedur ini memakan waktu selama 20 menit. Pada kelompok kontrol manset dipasang pada salah satu lengan atas subjek dan dibiarkan tidak dikembangkan selama 20 menit.

Selama operasi lama tindakan ligasi aorta diukur dan jika lama ligasi aorta lebih dari 20 menit maka penelitian dilanjutkan tetapi jika lama ligasi aorta kurang dari 20 menit maka subjek penelitian di drop out dari penelitian. Setelah dilakukan pembukaan ligasi aorta, pemantauan akan adanya aritmia dimulai sampai 24 jam kedepan. Setelah operasi selesai dan pasien di transfer ke ICU, pada perawatan jam ke 12, 24, 36, 48, 60 dan 72 jam perawatan dilakukan pemantauan produksi urine dan pengambilan sampel darah dan 
diperiksa kadar serum kreatinin.

Data yang terkumpul dilakukan cleaning, coding dan tabulasi. Data dikumpulkan dan diolah dengan menggunakan program computer SPSS 15.0 for windows.

\section{HASIL}

Sebanyak 30 pasien dewasa yang menjalani operasi bedah jantung masuk dalam kriteria inklusi penelitian. Pasien berkenan dimasukan dalam penelitian dan menandatangani informed concent. Selanjutnya pasien dikelompokkan dalam kelompok perlakuan (B) sebanyak 15 pasien dan kontrol (A) sebanyak 15 pasien. Karakteristik data penelitian disajikan dalam tabel 3. Rerata umur responden pada kelompok kontrol adalah 49,26 (SD 15,34) dan 40 (SD 13,97). Jenis Kelamin laki-laki dijumpai dengan jumlah yang lebih banyak pada kedua kelompok. BMI pada kelompok kontrol adalah 21,13 (SD 4,71) dan 21,86 (SD $3,68)$ pada kelompok perlakuan. Lama Klem Aorta dan CPB pada kelompok kontrol yaitu 45,53 (SD 23,15) dan 68,26 (SD 33,45) relatif lebih singkat jika dibandingkan kelompok perlakuan yaitu 53,33 (SD 19,24) dan 74,66 (SD $33,18)$.

Variabel Aritmia dan AKI setelah operasi jantung yang menjadi fokus utama dalam penelitian ini dijabarkan dalam tabel 4. Aritmia terjadi $73 \%$ pada kelompok kontrol dan $14 \%$ pada kelompok perlakuan dengan atrial fibrilasi merupakan jenis aritmia yang paling sering terjadi. AKI didapatkan pada $73 \%$ pasien pada kelompok kontrol dan 6\% pada kelompok perlakuan dengan AKI grade 1 dengan frekuensi terbanyak.

Dari gambar $10 \quad$ yang menunjukkan angka kejadian aritmia yang dianalisa setiap jam menunjukkan aritmia lebih banyak terjadi pada jam ke 6 setelah operasi dan menurun setelah 12 jam pasca operasi. Tindakan yang dilakukan untuk mengatasi aritmia yang terjadi juga dicatat dan didapatkan pemberian loading cairan beratahap merupakan tindakan yang paling sering dilakukan. Satu pasien membutuhkan pemberian amiodarone dan penggunaan Pace Maker untuk mengatasi aritmia yang terjadi dan 5 pasien mengalami perbaikan aritmia tanpa diberikan terapi yang tampak dalam Gambar 11.

Kadar kreatinin diukur setiap 12 jam sampai 72 jam setelah operasi pada kedua kelompok. Perbandingan rerata kadar kreatinin pada kedua kelompok disajikan dalam gambar 12. Produksi urine juga diukur dan dicatat setiap 12 jam sampai 72 jam setelah operasi pada kedua kelompok. Rerata produksi urine setiap 12 jam dihitung dan disajikan pada gambar 13 .

Rerata kadar kreatinin pada tiap waktu pengukuran setelah operasi bedah jantung pada kelompok perlakuan lebih rendah dibandingkan pada kelompok kontrol. Kurva rerata produksi urin pada kelompok perlakuan tampak lebih stabil bila dibandingkan kelompok kontrol. 
Analisis kemaknaan hubungan dari tindakan RIPC terhadap angka kejadian aritmia dan AKI melalui perhitungan statistik ditunjukkan pada tabel 5 dan 6.

Melalui uji normalitas saphiro-wilk didapatkan hasil $<0,05$ yang menunjukkan data tidak berdistribusi normal. Analisa statistik untuk mencari hubungan diantara 2 kelompok dilanjutkan dengan uji Mann-Whitney yang disajikan pada tabel 6 .

Melalui uji Mann-Whitney didapatkan hasil $\mathrm{P}=0,01$ untuk aritmia dan $\mathrm{P}=0,04$ untuk AKI yang menunjukkan variabel aritmia dan AKI berbeda bermakna. Tindakan RIPC menurunkan angka kejadian aritmia dan AKI setelah operasi bedah jantung yang berbeda bermakna melalui perhitungan statistik.

Hubungan antara kadar kreatinin dengan waktu pengukuran pada kedua kelompok dibandingkan dan dihitung dengan statistik. Dari tabel 7 dapat disimpulkan sebaran data tidak terdistribusi normal pada variabel kontrol jam ke 36, 48 dan 60 sehingga analisa statistik dilanjutkan dengan uji Mann-Whitney untuk jam ke 36, 48 dan 60 sedangkan untuk jam ke 12, 24 dan 72 dengan data terdistribusi normal analisa statistik dilanjutkan dengan uji Independent Samples $T$ Test. Didapatkan pengukuran kadar kreatinin terhadap waktu pengukuran yang secara statistik bermakna pada jam ke 36,48 , 60 dan 72.

\section{PEMBAHASAN}

Prosedur RIPC pada penelitian ini dilakukan dengan pengembangan manset sampai $200 \mathrm{mmHg}$ dan dipertahankan selama 5 menit dan dilanjutkan pengempisan manset selama 5 menit dimana siklus ini dilakukan sebanyak 2 kali dengan total waktu prosedur 20 menit. Tindakan ini lebih singkat dengan beberapa penelitian sebelumnya oleh Hausenloy DJ et al, Venugopal V et al, Thielmann $M$ et al dan Zimmerman RF et al yang melakukan 3 siklus selama 30 menit. $^{8-11}$ Pada penelitian ini semua prosedur RIPC dapat diselesaikan sebelum dilakukan sternotomi sehingga prosedur RIPC ini dilakukan sebelum adanya stimulasi pembedahan sesuai dengan prosedur yang ditentukan dalam penelitian ini.

Aritmia dan AKI setelah operasi jantung merupakan komplikasi yang sering terjadi setelah opeasi bedah jantung. Kedua komplikasi tersebut mempengaruhi mortalitas pasien setelah operasi bedah jantung. Dalam penelitian ini Aritmia didapatkan pada 73\% pasien kelompok kontrol dan 14\% pada kelompok perlakuan. Atrial fibrilasi (AF) merupakan aritmia yang paling sering terjadi pada kelompok kontrol dan terjadi sebanyak $60 \%$ dimana hal ini sesuai dengan oleh Perreto $\mathrm{G}$ et al. yang menyatakan angka kejadian Atrial Fibrilasi mencapai 15\%$60 \%{ }^{12}$ Atrial fibrilasi setelah operasi jantung dapat meningkatkan risiko terjadinya stroke setelah operasi jantung, meningkatkan lama rawat ICU, delirium setelah operasi dan penurunan neurokognitif. ${ }^{13}$ 
Aritmia secara umum dapat disebabkan oleh faktor pasien dan faktor pembedahan. Faktor pasien adalah usia, adanya kelainan struktur jantung dan adanya penyakit komorbid ekstrakardial. Faktor pembedahan adalah trauma dan inflamasi, stress hemodinamik, cedera iskemia, obat obatan perioperatif, gangguan elektrolit dan ada tidaknya intervensi pada lapisan lemak di anterior jantung. ${ }^{12}$ Faktor penyebab yang lebih berpengeruh akan terjadinya aritmia setelah operasi merupakan hal yang kompleks dan mulfaktorial. Namun Burgess et al menyatakan kejadian Aritmia setelah operasi jantung akan meningkat pada waktu yang akan datang seiring makin banyaknya populasi usia tua menjalani operasi jantung. ${ }^{13}$

Melalui pemantauan waktu terjadinya aritmia didapatkan puncak terjadinya aritmia pada jam ke 6 setelah operasi dan berangsur menurun setelah 12 jam. Perreto $G$ et al. Menyatakan AF setelah operasi jantung terjadi dalam beberapa hari pertama setelah pembedahan. AF seringkali sembuh dengan sendirinya dimana $15-30 \%$ AF kembali menjadi irama sinus dalam 2 jam dan $80 \%$ dalam 24 jam setelah operasi pada pasien tanpa ada riwayat AF sebelumnya. Rerata durasi AF setalah operasi jantung adalah 11-12 jam dan lebih dari 90\% pasien berada dalam irama sinus dalam 6 sampai 8 minggu setelah operasi. Penggunaan obat antiaritmia tampaknya tidak mengobati penyebab dari AF. ${ }^{12}$ Adanya perpindahan cairan instertisial mengakibatkan perubahan dalam kecukupan volume dan tekanan cairan yang dapat mempengaruhi neurohumoral dan kelistrikan pada atrium. $^{14}$ Dalam penelitian ini pemberaian loading cairan bertahap untuk mencapai kecukupan cairan merupakan tindakan awal dari terjadinya aritmia dan dilakukan pada sebagian besar kasus yang cukup efektif dalam mengatasi aritmia yang terjadi. Sebagian besar aritmia dapat hilang dengan sendirinya tanpa adanya intervensi.

RIPC menurunkan angka kejadia Aritmia pada kelompok perlakuan sebanyak 59\%. Melalui statistik, tindakan RIPC bermakna dalam mengurangi Aritmia pada kelompok perlakuan dibanding kontrol. Hal ini sesuai dengan penelitian oleh Jannati $M$ dan Kojuri $J$ et al yang menyatakan Iskemic Preconditioning secara signifkan mengurangi Atrial Fibrilasi setelah operasi CABG sehingga prosedur ini dapat digunakan sebaga pencegahan Atrial Fibrilasi. ${ }^{15}$ Namun prosedur preconditioning pada penelitian ini melalui klem langsung pada aorta. Pada penelitian sebelumnya oleh Candilio et al menyatakan RIPC dengan aplikasi manset bertekanan pada lengan dapat mengurangi atrial fibrilasi setelah operasi jantung melalui proteksi jantung terhadap IRI. ${ }^{16}$

AKI terjadi pada $11 \quad(73 \%)$ pasien di kelompok kontrol dan $1(6 \%)$ pasien pada kelompok perlakuan. Pada kelompok kontrol, 5 pasien mengalami AKI grade 1, 3 pasien mengalami AKI grade 2 dan 3 pasien mengalami AKI 
Grade 3. Angka kejadian AKI pada penelitian ini lebih besar daripada yang diungkapkan oleh Rosner $\mathrm{MH}$ dan Okusa MD dimana AKI setelah operasi jantung mencapai 30\%. ${ }^{17}$ Lebih tingginya angka keadian AKI pada penelitian ini diakibatkan oleh banyak faktor yang terjadi sebelum operasi, selama operasi dan setelah operasi yang disimpulkan pada tabel 2. Lagny MG et al menyatakan patofisiologi terjadinya AKI setelah operasi bersifat multifaktorial. Dalam penelitiannnya faktor yang meningkatkan risiko AKI adalah usia yang lebih tua dan BMI yang lebih tinggi. ${ }^{18}$

Penggunaan dari CPB dapat meningkatkan angka kejadian AKI setelah operasi. ${ }^{17-19}$ Dalam penelitian ini didapatkan rerata durasi CPB pada kelompok kontrol adalah 68,26 dan 74,66 pada kelompok perlakuan. Sedangkan angka kejadian AKI pada kelompok kontrol adalah $73 \%$ dan kelompok perlakuakn 6\%. Hal ini menunjukkan walaupun kelompok perlakuan mendapatkan durasi CPB yang lebih lama namun mendapatkan angkan kejadian AKI yang lebih sedikit. Reents W et al dan Arg AX et al membandingkan angka kejadian AKI pada kelompok on pump dan off pump pada operasi CABG dan mendapatkan off pump CABG tidak mengurangi angka kejadian AKI setelah operasi CABG. ${ }^{20,21}$ Hal ini menunjukkan bahwa penggunaan $\mathrm{CPB}$ bukan merupakan faktor tunggal dalam terjadinya AKI setelah operasi bedah jantung.

Dalam penelitian ini kadar kreatinin pada kedua kelompok dibandingkan pada tiap penukuran dan didapatkan hasil yang berbeda bermakna pada pengukuran jam ke 36 , 48, 60 dan 72. Hasil ini mendekati penelitian oleh Mao $\mathrm{H}$ et al. yang menyatakan perubahan dari kreatinin pada umumnya terjadi setelah 48 jam setelah operasi. $^{22}$

RIPC dapat mengurangi kejadian AKI setelah operasi jantung yang bermakna dengan penghitungan statsistik. RIPC dapat mengurangi kejadian AKI melalui perannya sebagai protektor organ. Hal ini sesuai dengan Venugopal $\mathrm{V}$ et al yang menyatakan RIPC dengan tiga siklus lima menit iskemia dan lima menit reperfusi dapat menurunkan angka kejadian AKI setelah operasi $\mathrm{CABG} .{ }^{23}$ Zimmerman et al juga menyatakan RIPC dengan tiga siklus lima menit iskemia dan lima menit reperfusi dapat menurunkan angka kejadian AKI setelah operasi $\mathrm{CABG}^{24}$

Penulis tidak mendapatkan adanya komplikasi lokal dari pemberian prosedur RIPC. Menurut Eckert dan Schnackerz K dalam Ischemic tolerance of human skeletal muscle menyatakan bahwa batas maksimal dari waktu iskemia pada otot rangka adalah 2,25 jam sehingga iskemia selama 5 menit pada otot rangka aman untuk dilakukan dan bersifat tidak mematikan. ${ }^{25}$ Beberapa penelitian sebelumya pada manusia menyatakan RIPC merupakan protokol yang aman. Kloner RA menyatakan bahwa RIPC merupakan prosedur yang aman, efektif, tidak invasif dan murah untuk mengurangi kerusakan jantung pada keadaan 
dimana iskemia otot jantung akan terjadi. Iskemia lengan yang dilakukan tidak menyebabkan efek samping. Zarbock A et al menyatakan RIPC secara signifikan mengurangi kejadian AKI dan mengurangi penggunaan renal replacement therapy pada pasien setelah operasi jantung dan tidak ada efek samping yang didapatkan berkaitan dengan tindakan RIPC. Dalam penelitian lainnya oleh Cheung MMH et al menyatakan bahwa tidak didapatkan efek samping lokal yang dilaporkan akibat stimulus RIPC. Marczaka $\mathrm{J}$ et al menyatakan RIPC adalah protokol aman yang dapat digunakan dalam operasi jantung untuk memberikan perlindungan jantung terhadap cedera iskemia reperfusi. ${ }^{26-29}$

\section{SIMPULAN}

RIPC dapat mengurangi angka kejadian aritmia dan AKI setelah operasi jantung secara bermakna. Berkurangnya angka kejadian aritmia pada kelompok RIPC membuktikan adanya mekanisme kardioprotektif, mencegah kematian sel otot jantung, mencegah terjadinya inhomogenitas durasi potensial aksi, mencegah reentry dari potensial aksi otot jantung dan mencegah aritmia.Berkurangnya angka kejadian AKI pada kelompok perlakuan menunjukkan RIPC juga memiliki efek protektor organ ginjal.

Pada penelitian ini RIPC dilakukan dengan 2 siklus iskemia dan reperfusi. Hal ini menunjukkan 2 siklus RIPC cukup untuk memberikan efek proteksi terhadap jantung dan ginjal pada tindakan klem aorta lebih dari 20 menit. 


\section{DAFTAR PUSTAKA}

1. Siravaman V, Pickard JMJ, Hausenloy DJ. Remote ischaemic conditioning: cardiac protection from afar. Anaesthesia. 2015; 70: $732-48$

2. Malbouisson LMS, Santos LMD, Auler JOC, Carmona MJC. Myocardial protection in cardiac surgery. Rev. Bras. Anestesiol. 2005; 55( 5 ): 558-74

3. Al-Sarraf N, Thalib L, Hughes A, Houlihan M, Tolan M, Youg V, et al. Cross-clamp time is an independent predictor of mortality and morbidity in low- and high-risk cardiac patients. International Journal of Surgery. 2011; 9:104-9

4. Verma S, Fedak PWM, Weisel RD, Butany J, Rao V, Maitland A, et al. Fundamentals of Reperfusion Injury for the Clinical Cardiologist. Circulation. 2002; 105:2332-6

5. Schopka S, Diez C, Camboni D, Floerchinger B, Schmid C, Hilker M. Impact of cardiopulmonary bypass on acute kidney injury following coronary artery bypass grafting: a matched pair analysis. Journal of Cardiothoracic Surgery. 2014; 9:20

6. Shi W, Johansen JV, Endogenous cardioprotection by ischaemic postconditioning and remote conditioning. Cardiovascular Research. 2012; 94: 206-16

7. Gassanov N, Nia AM, Caglayan E, Fikret R, Remote Ischemic Preconditioning and Renoprotection: From Myth to a Novel Therapeutic Option?. J Am Soc Nephrol. 2014; 25: 216-24

8. Thielman M, Kattenberg E, Kleinbongard P, Wendt D, Gedik N,
Pasa S, Cardioprotective and prognostic effects of remote ischaemic preconditioning in patients undergoing coronary artery bypass surgery: a single-centre randomised, double-blind, controlled trial. Lancet. 2013; 382: 597-604

9. Hausenloy DJ, Mwamure PK, Venugopal V, et al. Effect of remote ischaemic preconditioning on myocardial injury in patients undergoing coronary artery bypass graft surgery: a randomised controlled trial. Lancet. 2007; 370: 575-9

10. Venugopal V, Hausenloy DJ, Ludman A, et al. Remote ischaemic preconditioning reduces myocardial injury in patients undergoing cardiac surgery with cold-blood cardioplegia: a randomised controlled trial. Heart. 2009; 95: 1567-71

11. Thielmann M, Kottenberg E, Boengler K, et al. Remote ischemic preconditioning reduces myocardial injury after coronary artery bypass surgery with crystalloid cardioplegic arrest. Basic Research in Cardiology. 2010; 105: 657-64

12. Peretto G, Durante A, Limite LR, Cianflone D. Postoperative Arrhythmias after Cardiac Surgery: Incidence, Risk Factors, and Therapeutic

Management, Cardiology Research and Practice. 2014; 1:1-15

13. Burgess DC, Kilborn MJ, Keech AC. Interventions for prevention of post-operative atrial fibrillation and its complications after cardiac surgery: a meta-analysis. European Heart Journal. 2006; 27 (23): 28462857 
14. Ommen SR, Odell JA, Stanton MS. Atrial Arrhythmias after Cardiothoracic Surgery. N Engl J Med. 1997; 336:1429-34

15. Jannati M, Kojuri J. Ischemic Preconditioning and Atrial Fibrillation after Coronary Artery Bypass Grafting Surgery. Iranian Cardiovascular Research Journal. 2008; 1 (2): 38-41

16. Candilio L, Malik A, Ariti C, Barnard M, Salvo CD, Lawrence D, et al. Hear Effect of remote ischaemic preconditioning on clinical outcomes in patients undergoing cardiac bypass surgery: a randomised controlled clinical trial. Heart. 2015;101:185-92

17. Rosner MH, Okusa MD. Acute Kidney Injury Associated with Cardiac Surgery. Clin J Am Soc Nephrol. 2006; 1: 19-32

18. Lagny MG, Jouret $\mathrm{F}$, Koch JN, Blaffart F, Donneau AF, Albert A. Incidence and outcomes of acute kidney injury after cardiac surgery using either criteria of the RIFLE classification. BMC Nephrology. 2015;16:76

19. Paarman H, Charitos EI, Beilharz A, Heinze H, Schon J, Berggreen A et al. Duration of cardiopulmonary bypass is an important confounder when using biomarkers for early diagnosis of acute kidney injury in cardiac surgical patients. Applied Cardiopulmonary Pathophysiology. 2013; 17: 284-297

20. Reents W, Hilker M, Börgermann J, Albert M, Plötze K, Zacher $M$ et al. Acute kidney injury after on-pump or off-pump coronary artery bypass grafting in elderly patients. Ann Thorac Surg. 2014 Jul;98(1):9-14
21. Garg AX, Devereaux PJ, Yusuf S, Cuerden MS, Parikh CR, Coca SG et al. Kidney function after off-pump or on-pump coronary artery bypass graft surgery: a randomized clinical trial. JAMA. 2014;311(21):2191-8

22. Mao H, Katz N, Ariyanon W, Blanca -Martos L, Adýbelli Z, Giuliani A et al. Cardiac Surgery-Associated Acute Kidney Injury. Cardiorenal Med 2013; 3: 178-99

23. Venugopal V, Laing CM, Ludman A, Yellon DM, Hausenloy D: Effect of remote ischemic preconditioning on acute kidney injury in nondiabetic patients undergoing coronary artery bypass graft surgery: A secondary analysis of 2 small randomized trials. Am J Kidney Dis. 2010; 56: 1043-9

24. Zimmerman RF, Ezeanuna PU, Kane JC, Cleland CD, Kempananjappa TJ, Lucas FL, Kramer RS: Ischemic preconditioning at a remote site prevents acute kidney injury in patients following cardiac surgery. Kidney Int. 2011; 80: 861-7

25. Eckert P, Schnackerz K. Ischemic tolerance of human skeletal muscle. Ann Plast Surg. 1991;26(1):77-84

26. Marczak J, Nowicki R, Kulbacka J, Saczko J, Is remote ischaemic preconditioning of benefit to patients undergoing cardiac surgery? Interactive CardioVascular and Thoracic Surgery. 2012; 14:634-9

27. Kloner RA. Clinical Application of Remote Ischemic Preconditioning. Circulation. 2009; 119: 776-778

28. Zarbock A, Schmidt C, Van Aken H, Wempe C, Martens S, Zahn PK et al. Effect of remote ischemic preconditioning on kidney injury 
among high-risk patients undergoing cardiac surgery: a randomized clinical trial. JAMA. 2015;313 (21):2133-41

29. Cheung MM, Kharbanda RK, Konstantinov IE, Shimizu M, Frndova H, Li J et al. Randomized controlled trial of the effects of remote ischemic preconditioning on children undergoing cardiac surgery: first clinical application in humans. J Am Coll Cardiol. 2006;47(11):227782 